\title{
Discharging sinus from the eyelid following accidental impaction of wood fragment
}

\author{
Olusola J. Omotoye ${ }^{1}$, Stella A. Adegbehingbe ${ }^{2}$, lyiade A. Ajayi ${ }^{1}$
}

${ }^{1}$ Department of Ophthalmology, Ekiti State University Teaching Hospital, Ado-Ekiti, Nigeria; 'Department of Ophthalmology, University of Medical Sciences Teaching Hospital Complex, Akure, Nigeria

\section{Abstract}

Injury to the eyelid is one of the most common emergencies at eye hospitals. Injuries to the eye and its surrounding tissues may result from several types of foreign bodies. The injured eye must be carefully and gently examined to prevent missed injuries and to avoid putting pressure on the globe, which might cause prolapse of intraocular contents.

We report an unsightly upper eyelid discharging sinus with wood fragment impaction that was incompletely removed by the first attending physician for a period of eleven months. The wood fragments were carefully and completely removed under local anaesthesia, and debridement and dressing of the wound were done by an ophthalmic plastic surgeon when the patient was eventually referred to the tertiary institution. The need to include basic eye care courses in continued medical education for all general practitioners is advocated to reduce resultant ocular morbidity from such ocular injuries. This will aid this group of physicians in decision-making while providing care to patients with eye injuries.

Keywords: discharging sinus, eyelid, impaction, injury

Correspondence: Dr. Olusola J. Omotoye, Department of Ophthalmology, Ekiti State University Teaching Hospital, Ado-Ekiti, Ekiti State, Nigeria.

E-mail: layoshol@yahoo.com 


\section{Sinus bernanah dari kelopak mata akibat serpihan kayu terbenam berikutan kemalangan yang tidak disengajakan}

\section{Abstrak}

Kecederaan pada kelopak mata adalah salah satu kes kecemasan sering dirawat di hospital mata. Kecederaan pada mata dan tisu di sekitarnya mungkin disebabkan oleh beberapa jenis badan asing. Mata yang cedera mesti diperiksa dengan cermat dan berhati-hati untuk mengelakkan kecederaan yang terlepas dari pengesanan dan mengelakkan dari memberi tekanan pada bola mata, yang mungkin menyebabkan berlakunya prolaps kandungan intraokular.

Kami melaporkan kes kecederaan pada kelopak mata atas yang membentuk sinus akibat serpihan kayu yang tidak dikeluarkan sepenuhnya oleh doktor yang merawat buat pertama kali setelah sebelas bulan berlalu. Pesakit dirujuk ke hospital tertiari dimana serpihan kayu dikeluarkan dengan hati-hati dan sepenuhnya di bawah bius setempat, dan dibersihkan sepenuhnya serta dibalut oleh pakar bedah plastik oftalmik. Adalah penting untuk kursus penjagaan mata asas menjadi sebahagian dari pendidikan perubatan yang berterusan untuk semua pengamal perubatan am bagi mengurangkan morbiditi okular akibat kecederaan mata seperti ini. Ini akan membantu pengamal perubatan am dalam membuat keputusan dalam merawat pesakit yang mengalami kecederaan mata dengan lebih baik.

Kata kunci: kecederaan, kelopak mata, pengecutan, sinus bernanah

\section{Introduction}

The eye is the third most common organ affected by injuries after the hands and feet. ${ }^{1}$ However, injury to the eyelid is one of the most common emergencies at eye hospitals. ${ }^{2}$ Injuries to the eye and its surrounding tissues may result from several types of foreign bodies, which will determine the clinical presentation of the patient. ${ }^{3}$ The need to carefully examine the injured eye is germane since some penetrating eye injuries can easily be missed; some injuries may be self-sealing and signs of abnormality are subtle. ${ }^{2} A$ visual acuity of $6 / 6$ in a penetrating eye injury does not necessarily exclude serious problems apart from the resultant ocular deformity. Therefore, specific signs must be closely investigated, otherwise they may be easily missed. ${ }^{2}$ The deformity can have a negative psychosocial impact as well as lowered self-worth and health-related quality of life for the injured patient. ${ }^{4}$ 
Inability to recognize the complete removal of organic foreign body from the eyelid by the managing non-ophthalmic doctor and failure to appropriately refer to a specialist can result in secondary infection with aesthetically unacceptable complications.

We report a cosmetically unsightly upper eyelid discharging sinus due to incomplete removal of impacted wood fragment by the non-specialist physician that provided care for the injured patient, who presented to our hospital eleven months after the event.

\section{Case report}

A 45-year-old male passenger on motorcycle accidentally hit his right eye on a plank and some fragments of wood got impacted on the eyelid eleven months before presenting to our facility. There was bleeding from the site of injury and he developed pain in the eye but there was no loss of consciousness. He was taken to a general hospital, where some wood fragments were removed. The non-specialist physician who provided emergency care to the patient thought the impacted wood fragments had been completely removed. He subsequently dressed the wound and prescribed systemic antibiotics and oral analgesic. He was placed on daily dressing in the general hospital facility.

Eleven months after the accident, the patient noticed copious discharge and a protruding foreign body from the wound site, which had not healed. This prompted the patient to visit a private eyeclinic, where antifungal and antibiotic eye medications were prescribed. He was then referred to our tertiary facility. He was not a known diabetic and had no history suggestive of diabetes mellitus. On examination, a very apprehensive patient was seen with stable vital signs. Ocular examination revealed

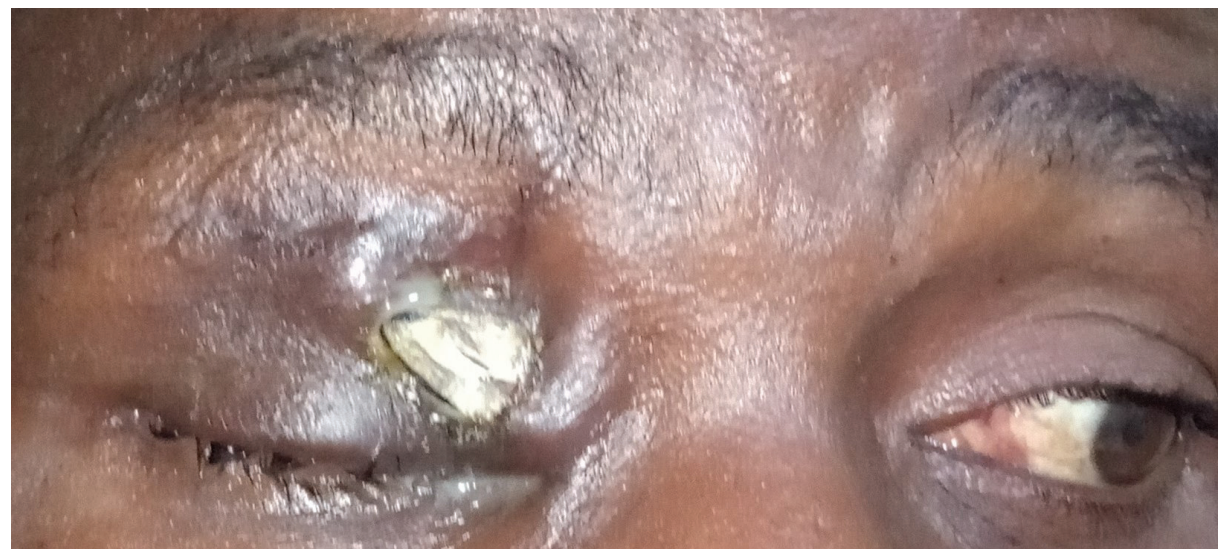

Fig. 1. The patient with foreign body impaction of the upper eyelid. 


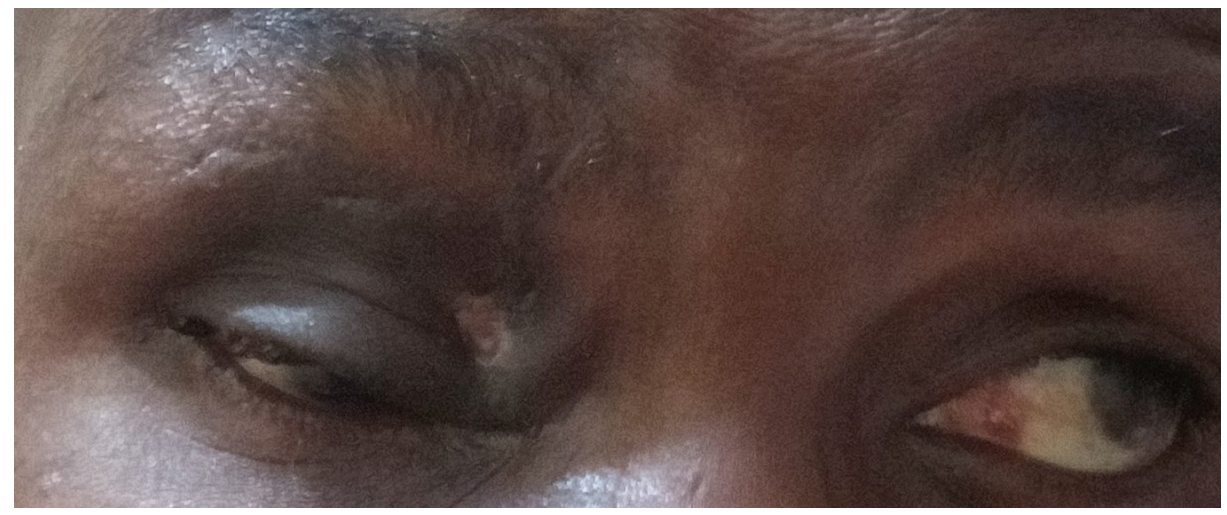

Fig. 2. Postoperative state with healed scar and upper eyelid ptosis.

a visual acuity of 6/36 in the right eye and 6/5 in the left eye. There was complete mechanical ptosis in the right eye and fumigating, foul-smelling, copious discharge on the right upper eyelid (Fig. 1). A discharging sinus involving the medial third of the right upper eyelid with a protruding whitish foreign body on the eyelid was observed. There were no other ocular findings in both the anterior and posterior segments. The working diagnosis of right upper eyelid discharging sinus with impacted wood fragment secondary to road traffic accident was made. The patient was taken to the procedure room, where the eye was cleaned with $10 \%$ povidone iodine and draped, topical tetracaine applied, and $2 \%$ xylocaine with adrenaline was infiltrated around the wound site. The fragments of the wound were carefully removed using micro-artery forceps. Haemostasis was secured. Debridement was performed, the wound was dressed, and the patient was prescribed oral cefuroxime $500 \mathrm{mg}$ bd, metronidazole $500 \mathrm{mg}$ tds, analgesic, and topical antibiotics. The removed fragments were sent for microscopic culture and sensitivity. Daily dressing was done for one week and the wound healed with scarring and residual ptosis (Fig. 2).

\section{Discussion}

Management of eye injuries has been documented to pose difficult dilemmas. ${ }^{5}$ However, the standard practice is to undertake primary surgical repair to restore structural integrity of the globe and the adnexa after a careful examination of the eye. ${ }^{5}$ This will reduce the possibility of any resultant ocular deformity that can cause negative psychosocial effects on the patient. It has been reported that when there is penetrating eyelid injury, objects may easily penetrate the orbit and even the cranial cavity through the orbit. ${ }^{2}$ Therefore, examination should be very gentle to avoid putting pressure on the globe, which might cause prolapse of intraocular contents. ${ }^{2}$ 
The case that presented in this tertiary facility was a young man in an economically productive age group, the breadwinner of the family who was doing legitimate daily activities, and who was at risk of eye trauma. ${ }^{6}$ Unfortunately, the patient was not seen by an ophthalmic specialist because there were none in the health facility. Moreover, he was not referred timely and appropriately. This caused the patient to experience undue pain and unnecessary loss of time and revenue, which could have been reduced by appropriate referral. This emphasizes the need for a good referral network between the primary eye care level and tertiary eye care level - where these ophthalmic specialists are available - to be established in Nigeria. Moreover, continued medical education for all general practitioners should include basic eye care courses to aid them in decision-making while providing care to patients such as the one this case. Although delayed presentation is common in many eye injuries, ${ }^{7}$ this patient presented within 24 hours of injury. Unfortunately, his emergency was not managed adequately by the attending physician due to the lack of prerequisite knowledge of management of ocular injuries, which resulted in avoidable ocular morbidity in this patient.

\section{Conclusion}

A cosmetically unsightly discharging sinus arising from accidental, prolonged impacted wood fragment in the upper eyelid was properly managed. The need to include basic eye care courses in continued medical education for all general practitioners is advocated. This will aid this group of physicians in decision-making while providing care to patients with eye injuries.

\section{References}

1. Nordberg E. Injuries as a public health problem in sub-Saharan Africa: epidemiology and prospects for control. East Afr Med J. 2000;77(12 Suppl):S1-43.

2. Khaw P, Shah P, Elkington A. Injury to the eye. BMJ. 2004;328(7430):36-38.

3. Wasfi E, Kendrick B, Yasen T, Varma P, Abd-Elsayed AA. Penetrating eyelid injury: a case report and review of literature. Head Face Med. 2009;5(1):2.

4. Balogun BG, Adekoya BJ, Balogun MM, Ehikhamen OA. Orbito-oculoplastic diseases in lagos: a 4-year prospective study. Middle East Afr J Ophthalmol. 2014;21(3):236.

5. Rahman I, Maino A, Devadason D, Leatherbarrow B. Open globe injuries: factors predictive of poor outcome. Eye. 2006;20(12):1336.

6. Okoye O. Eye injury requiring hospitalisation in Enugu, Nigeria: A one-year survey. Niger J Surg. 2006;8(1).

7. Addisu Z. Pattern of ocular trauma seen in Grarbet Hospital, Butajira, central Ethiopia. Ethiop J Health Dev. 2011;25(2):150-155. 